\title{
BOREHOLE DATA-COLLECTION METHODS APPLICABLE FOR THE REGIONAL OBSERVATION AND MONITOR WELL PROGRAM, SOUTHWEST FLORIDA WATER MANAGEMENT DISTRICT
}

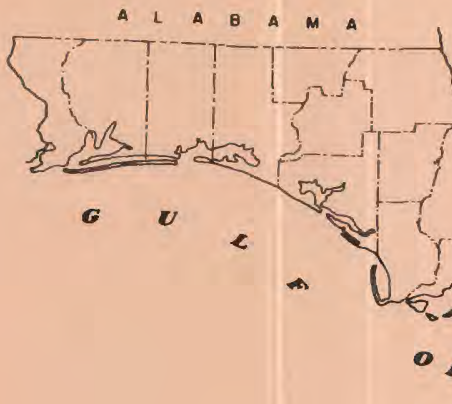

U.S. GEOLOGICAL SURVEY

WATER-RESOURCES INVESTIGATIONS 81.57

Prepared in cooperation with the

$\times$ * -

SOUTHWEST FLORIDA WATER MANAGEMENT DISTRICT 


\begin{tabular}{|l|l|l|}
\hline REPORT DOCUMENTATION & 1. REPORT NO. & 2. \\
\hline PAGE
\end{tabular}

\section{Title and Subtitle}

BOREHOLE DATA-COLLECTION METHODS APPLICABLE FOR THE REGIONAL

OBSERVATION AND MONITOR WELL PROGRAM, SOUTHWEST FLORIDA WATER MANAGEMENT DISTRICT

7. Author(s)

John J. Hickey

9. Performing Organization Name and Address

U.S. Geological Survey, Water Resources Division

325 John Knox Road, Suite F-240

Tallahassee, Florida 32303

3. Recipient's Accession No.

5. Report Date

September 1981

6.

8. Performing Organization Rept. No USGS/WRI 81-57

10. Project/Task/Work Unit No.

11. Contract(C) or Grant(G) No.

(C)

(G)

\section{Sponsoring Organization Name and Address}

13. Type of Report \& Period Covered

U.S. Geologica1 Survey, Water Resources Division

325 John Knox Road, Suite F-240

Tallahassee, Florida 32303

14.

15. Supplementary Notes

Prepared in cooperation with the Southwest Florida Water Management District

16. Abstract (Limit: 200 words)

Management of ground-water resources within the Southwest Florida Water Management District requires that hydrogeologic characteristics of water-bearing rocks and quality characteristics of water be described. Wells for the District's Regional Observation and Monitor Well Program are drilled specifically to collect data to describe the groundwater resource. Borehole data-collection methods for these wells include drilling in stages; running geophysical logs at the completion of each stage; collection of waterlevel and specific-conductance data before, during, and after a day's drilling; specificcapacity determinations after a day's drilling; and placing a packer in the gypsiferous and anhydritic limestone and dolomite for water-level and water-quality data.

17. Document Analysis a. Descriptors

Drilling, Borehole geophysics, Carbonate rocks, Florida

b. Identifiers/Open-Ended Terms

Floridan aquifer

c. COSATI Field/Group

18. Availability Statement

No restriction on distribution
19. Security Class (This Report) UNCLASSIFIED
20. Security Class (This Page) UNCLASSIFIED

21. No. of Pages 14

22. Price 
BOREHOLE DATA-COLLECTION METHODS APPLICABLE FOR THE REGIONAL OBSERVATION AND MONITOR WELL PROGRAM, SOUTHWEST FLORIDA WATER MANAGEMENT DISTRICT

By John J. Hickey

U.S. GEOLOGICAL SURVEY

Water-Resources Investigations 81-57

Prepared in cooperation with the SOUTHWEST FLORIDA WATER MANAGEMENT DISTRICT

Tallahassee, Florida

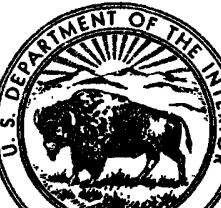




\section{UNITED STATES DEPARTMENT OF THE INTERIOR \\ JAMES G. WATT, Secretary}

GEOLOGICAL SURVEY

Doyle G. Frederick, Acting Director

For additional information write to:

U.S. Geological Survey

325 John Knox Road, Suite F-240

Tallahassee, Florida 32303 
CONTENTS

Abstract -

Introduction -

Generalized hydrogeologic setting of the Southwest Florida Water

Management District -

Objectives of borehole data collection - 4

Practical limitations in achieving borehole data-collection objectives -- 4

Borehole data-collection methods - 5

References - 10

\section{ILLUSTRATION}

Page

Figure 1. Map showing location of the Southwest Florida Water Management District _- 3

TABLE

Page

Table 1. Summary of borehole data-collection methods -_-_-_-_-_-_-_ 9 

BOREHOLE DATA-COLLECTION METHODS APPLICABLE FOR THE REGIONAL OBSERVATION

AND MONITOR WELL PROGRAM, SOUTHWEST FLORIDA WATER MANAGEMENT DISTRICT

By John J. Hickey

\begin{abstract}
Management of ground-water resources within the Southwest Florida Water Management District requires that hydrogeologic characteristics of waterbearing rocks and quality characteristics of water be determined and described. Wells for the District's Regional Observation and Monitor Well Program are drilled specifically to collect data to describe the ground-water resource. Borehole data-collection methods that can be used during construction of these wells include drilling in stages; running geophysical logs at the completion of each stage; collection of water-level and specific-conductance data before, during, and after a day's drilling; specific capacity determinations after a day's drilling; and placing a packer in the gypsiferous and anhydritic limestone and dolomite for determining water-level and water-qualịty data.
\end{abstract}

INTRODUCTION

Management of ground-water resources within the Southwest Florida Water Management District requires that hydrogeologic characteristics of the waterbearing rocks and quality characteristics of the water be determined and described. Data for describing these characteristics come from boreholes. Generally, hydrologists collect data from wells drilled to produce water rather than from wells drilled to acquire data. This is a limitation on hydrologicdata collection and is one of the principal reasons for creation of the District's Regional Observation and Monitor Well Program (ROMP). Wells for this program are drilled specifically to collect data to describe the groundwater resource.

This report presents some borehole data-collection methods that can be used during the drilling of ROMP or other wells where data collection is a prime objective. Hydraulic, water-quality, and geophysical data-collection methods applicable to the hydrogeology of west-central florida are emphasized.

All the methods have been used and tested during extensive drilling at proposed wastewater-injection sites in Pinellas County and at proposed phosphate mining sites in Manatee County. The following brief sketch of these methods will not provide all data-collection answers, but can provide general guidelines for developing a data-collection program that can aid in achieving the goals of ROMP. 
The data-collection methods will not significantly increase the time needed to drill ROMP wells. If all methods were used, about 6 to 10 days might be added to the drilling time. This is a small increment, considering it could take from 90 to 180 days, or longer, to drill a well to the base of the Floridan aquifer in the Southwest Florida Water Management District. In practice, all of the methods probably would not have to be used during the drilling of every well. Prior hydrogeologic knowledge of the site and specific purpose of the ROMP well will guide the choice of methods used.

Some examples of data collected using the suggested methods are published in William F. Guyton and Associates (1976a; 1976b), Hickey (1977; 1979), and Hickey and Barr (1979).

The author wishes to thank W. B. Smith, Senior Hydrologist, of the Southwest Florida Water Management District for his thoughtful comments during the preparation of this report.

\author{
GENERALIZED HYDROGEOLOGIC SETTING OF
}

THE SOUTHWEST FLORIDA WATER MANAGEMENT DISTRICT

The Southwest Florida Water Management District (fig. 1) is underlain by three principal lithologic sequences. They are from top to bottom: (1) Unconsolidated sand, clay, and marl with some interbedded limestone and dolomite; (2) limestone, dolomitic limestone, and dolomite; and (3) gypsiferous and anhydritic limestone and dolomite. Total thickness of all three sequences ranges from about 4,000 feet in the northern part of the District to more than 13,000 feet in the southern part (Applin, 1951).

Ground-water resources in the District occur within the two uppermost lithologic sequences. Generally, the resource extends to depths below land surface not exceeding about 1,000 feet in the north and about 2,000 to 3,000 feet in the south. Along the Gulf coastal margins and in some southern areas of the District, the resource is at substantially shallower depths.

The surficial aquifer and the upper confining bed of the Floridan aquifer are in the uppermost lithologic sequence. The interbedded limestones and dolomites of this sequence occur in the southern part of the District within the upper confining bed of the Floridan aquifer. Locally, some of the limestone and dolomite beds have water-producing intervals that are used as a source of small water supply.

The Floridan aquifer is in the lithologic sequence composed of limestone, dolomitic limestone, and dolomite. The upper part of the aquifer is generally limestone, and the lower part of the aquifer is generally dolomitic limestone and dolomite. Water-producing intervals occur at various depths in the aquifer. The producing intervals in the dolomitic limestone and dolomite are generally more permeable than those in the limestone. Along coastal margins of the District, it is particularly important to identify the depths of water-producing intervals because they are the principal conduits of lateral ground-water flow and may be subject to saltwater intrusion. 


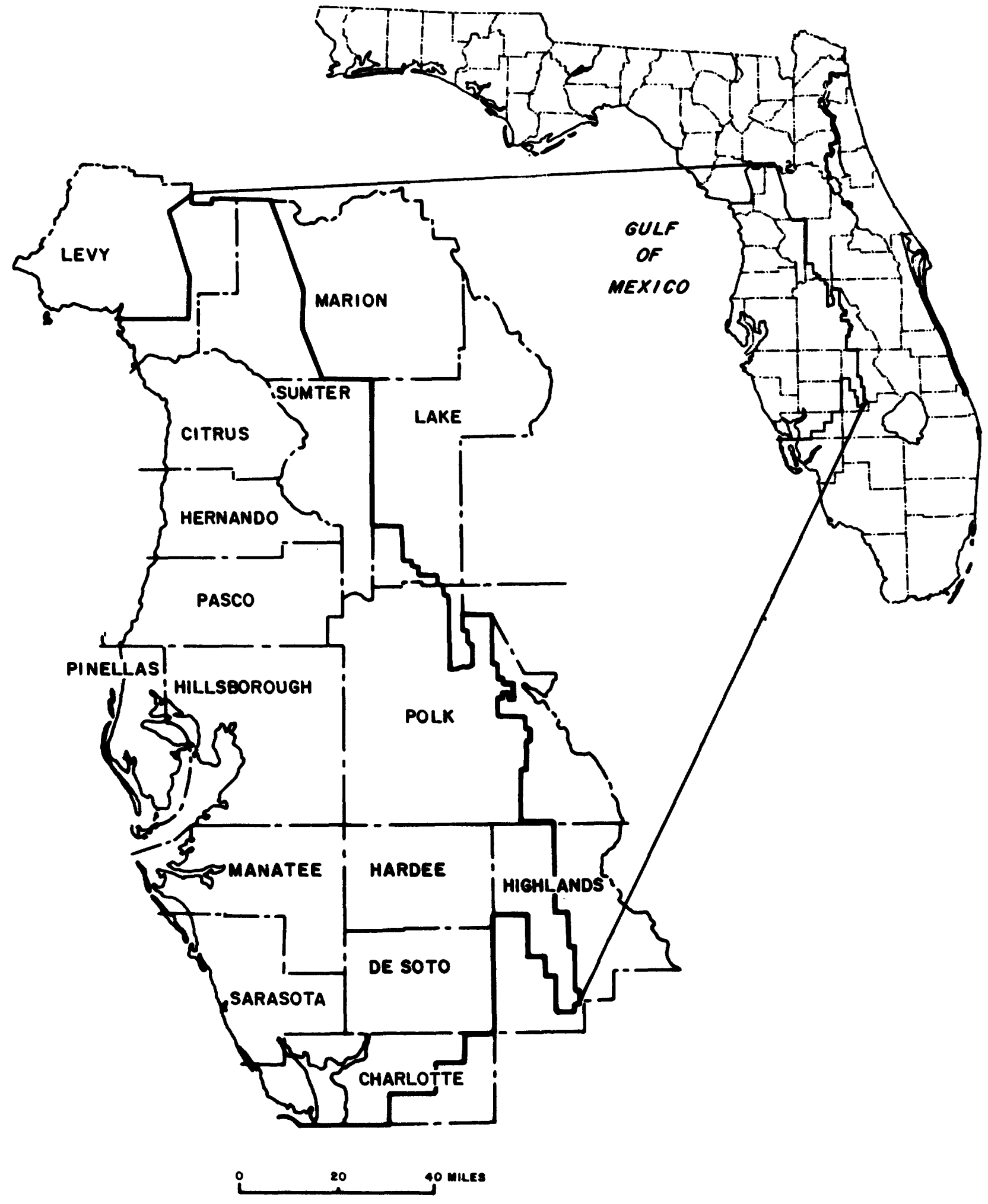

Figure 1.--Location of the Southwest Florida Water Management District. (District boundary is shown as solid line.) 
The lower confining bed of the Floridan aquifer is in the 1ithologic sequence composed of gypsiferous and anhydritic limestone and dolomite. Generally, the lower confining bed contains very poor quality water with high chloride and sulfate concentrations.

\section{OBJECTIVES OF BOREHOLE DATA COLLECTION}

Objectives of borehole data collection from ROMP wells in the Southwest Florida Water Management District are to:

1. Determine thickness, 1ithology, and hydrologic properties of the surficial aquifer, the upper and lower confining beds of the Floridan aquifer, and the Floridan aquifer;

2. Determine depth of water-producing intervals within the upper confining bed and Floridan aquifer and their relative producing capabilities;

3. Determine chemical characteristics of water within the surficial aquifer, upper confining bed, Floridan aquifer, and the top of the lower confining bed;

4. Determine direction of ground-water movement between the surficial aquifer and the Floridan aquifer, between water-producing intervals within the Floridan aquifer, and between the Floridan aquifer and the lower confining bed; and

5. Verify construction of the borehole.

\section{PRACTICAL LIMITATIONS IN ACHIEVING BOREHOLE DATA-COLLECTION OBJECTIVES}

The surficial aquifer and significant parts of the upper confining bed are composed of unconsolidated sediments, and boreholes in these are commonly drilled using either conventional mud-rotary or cable-tool methods. Mud-rotary drilling precludes water-quality determinations. Cable-tool drilling precludes the use of electric logs in the cased part of the hole, and the natural gamma ray, neutron, and gamma-gamma logs that can be run may be difficult to interpret because of the effects that the casing and disturbed beds have on the gamma and neutron flux.

Identification of moderate- to low-yielding water-producing intervals below highly productive intervals in the Floridan aquifer is extremely difficult unless the higher zones are cased of $f$. When pumped, most water produced in an open hole will come from the highly productive intervals, assuming there is little, if any, head difference between intervals.

Determination of chemical characteristics of water with depth in the Floridan aquifer during drilling is hampered because differences in flow from water-producing intervals mask the natural vertical variations in quality within the aquifer. As mentioned above, when pumped, most water produced in an open hole will come from the highly productive intervals, assuming there is 1ittle, if any, head difference between intervals. 
Some sections of limestone are friable, and borehole diameters are prone to enlarge to several times the bit diameter when drilled by the air reverserotary method. This problem is minimized when conventional mud-rotary or cable-tool methods are used. Some sections of dolomite are very fractured and borehole diameters may enlarge by collapse of the borehole wall during drilling. Large borehole diameters limit or negate interpretability of geophysical logs because the geophysical response of the borehole overrides response of adjacent beds.

Determination of vertical direction of ground-water flow is very difficult to accomplish during drilling because head measured in the borehole is a composite of all heads encountered.

Improper site selection and preparation before drilling of test boreholes can significantly limit the achievement of data-collection objectives. Sites should be selected and prepared with specific objectives and data-collection methods in mind. For example, disposal of large volumes of pumped water of ten presents problems on flat, poorly drained areas; and if chemical composition of pumped water is significantly poorer than surface water or water in the surficial aquifer, special drilling and disposal methods may be required to prevent environmental damage.

\section{BOREHOLE DATA-COLLECTION METHODS}

Mud-rotary drilling facilitates data collection in the unconsolidated section because a suite of borehole geophysical logs can be run prior to setting casing. Logs may include, as a minimum, caliper, single-point resistance, and natural gamma ray. In addition, deep-focused and long- and short-normal resistivity could also be included; and if poor quality water is likely to be penetrated, a neutron log could be run for porosity estimates so that resistivity logs can be interpreted to indicate depth of poor quality water. Resistivity measurements are related to formation water quality and porosity.

Water-level and water-quality data from the mostly unconsolidated section could be collected by drilling a minimum of two shallow wells. One well tapping the surficial aquifer and the other tapping limestone and dolomite water-producing intervals within the upper confining bed of the Floridan aquifer could provide reliable data. Data-collection procedures for the latter well can be tailored to suit local conditions by using procedures similar to those in the above and following discussion.

Air reverse-rotary drilling facilitates the collection of water-quality and specific-capacity data in the consolidated carbonate section. Discharge during drilling should be as small as possible to limit washing out the friable limestone. Prior to each day's drilling for the purpose of determining whether poor quality water has been penetrated, water samples can be taken, beginning after the equivalent of one-half the drill stem volume has been discharged and continuing after each one-half drill stem volume and until several stem volumes have been discharged. At the end of each day, a water sample can also be taken after all cuttings have been removed from the hole. After analyzing all water samples in the field for specific conductance, a comparison between the several beginning and the ending specific-conductance values may indicate whether poor quality water has been penetrated. 
Static water-level measurements made before each day's drilling are recommended. Also, pumping water-level measurements made soon after the start of drilling and whenever a noticeable change in drilling rate occurs are recommended.

An approximate measure of specific capacity can be calculated at the end of the day's drilling by measuring discharge after all cuttings have been removed and by measuring water levels at the time of the discharge measurement and about 30 minutes after discharge ceases. A better determination of specific capacity can be calculated by pumping the borehole after water levels have recovered from a day's drilling. A constant discharge rate of about 200 gallons per minute (gal/min) and water-level measurements taken before and during pumping for at least 30 minutes may provide sufficient data. If water quality and, thus, density varies with depth, the borehole should be pumped in two steps with the discharge and water-level data from the second step used for calculating specific capacity. The second step could start at any time after specific conductance of the pumped water becomes constant. In this way, water-level changes caused by water-density changes would be minimized. When the first highly productive water-producing interval is reached during drilling, subsequent specific-capacity determinations may be discontinued.

The upper part of the Floridan aquifer is generally a limestone and the lower part is generally a dolomitized sequence composed of dolomitic limestone and dolomite. Typically, the dolomitic sequence is more permeable than the limestone. Because of this vertical difference in hydraulic properties, data collection is improved by drilling Floridan aquifer boreholes in stages. It is recommended that the first stage be drilled to the approximate base of the limestone. Then, a borehole geophysics survey can be performed including, as a minimum, static and pumping temperature, flow meter, caliper, and specific conductance.

To insure that geophysical logs may be interpreted, the borehole should have a diameter that generally does not exceed 12 inches and, if possible, should not exceed 8 inches. After drilling and pumping is completed, a minimum of 1 day of rest should be allowed, to enable the head and temperature to stabilize, before the static-temperature $\log$ is run. The pumping temperature $10 \mathrm{~g}$ can be run only after at least five borehole volumes have been discharged at a minimum rate of about $200 \mathrm{gal} / \mathrm{min}$ to insure that temperatures measured are those of water in the aquifer and not of the fluid in the borehole.

Pumping at rates from 300 to $500 \mathrm{gal} / \mathrm{min}$ in boreholes ranging from 8 to 12 inches in diameter may be sufficient for reliable flow-meter logs in the upper part of the Floridan aquifer. Continuous flow-meter logs are to be avoided because they can be readily interpreted only when the borehole diameter is constant. The depth-stationary type of $10 \mathrm{~g}$ generally gives the best results. Depths at which to place the flow meter can be determined from caliper and static- and pumping-temperature logs.

During pumping for temperature and flow-meter logs, water-level measurements can be made in the well to provide an estimate of specific capacity and possibly transmissivity of the open-hole section. When the hole is open only to the limestone, pumping rates of 200 to $500 \mathrm{gal} / \mathrm{min}$ may be sufficient to cause measurable drawdown changes with time. Water-level measurements should be taken over a minimum duration of about 150 minutes from start of pumping for pumping test interpretation. 
After water-producing intervals have been determined from either or both the temperature and flow-meter logs, a deep well sampler can be used to collect water samples from the lowermost producing interval. It is recommended that samples be measured in the field for temperature and specific conductance and analyzed in the laboratory, as a minimum, for dissolved solids, chloride, sulfate, and water density.

Upon completing data collection in the limestone, the borehole can then be drilled, if necessary, through the dolomitized sequence and into the upper 200 to 300 feet of the lower confining bed. A good index for identifying the top of the confining bed is the first presence of gypsum or anhydrite below the dolomitized sequence. The same geophysical logs and data-collection procedures discussed above for the limestone are recommended. In addition, natural gammaray, deep-focused and long- and short-normal resistivity, and acoustic velocity logs are also recommended.

When the hole is open to the entire dolomitic sequence, discharge for a pumping test would probably have to be in excess of that needed for a flowmeter log. A rate on the order of $1,000 \mathrm{gal} / \mathrm{min}$ or higher may be required for measurable drawdown changes with time.

After all other testing activities are completed, and again, if necessary, a packer at the end of the drill pipe can be placed into the hole below the first presence of gypsum for testing of the confining bed. Placement of the packer depends upon the diameter and shape of the drilled hole, as determined from the caliper log. Pumping of the open interval below the packer will enable one to obtain water samples for the same measurements and analyses mentioned above, and drawdown can be measured at frequent intervals over a duration of about 1,000 minutes for pumping test interpretation. Step-drawdown tests could also be performed when the packer is in place to estimate entrance and pipe losses. Because large drawdowns would be anticipated, air-lift pumping probably would have to be used. The rate of air-lift discharge may range from about $0.5 \mathrm{gal} / \mathrm{min}$ to about $50 \mathrm{gal} / \mathrm{min}$. Water-level recovery measurements probably should be made after all pumping ceases because they can be interpreted to suggest whether the zone below the packer was isolated from zones above the packer. A small diameter tubing designed to pass through the air-lift assembly and open to just above the packer would allow water-level measurements to be made during pumping and recovery.

Additional data-collection methods could be included for both the unconsolidated sand, clay, marl section and the consolidated carbonate section, depending upon the purpose of the well. The limestone could be cased off before drilling and testing the lower Floridan aquifer and confining bed. This would be reasonable if highly productive intervals are found within the limestone and the purpose of the well is to test and monitor the dolomitic sequence of the aquifer or the lower confining bed.

Neutron and gamma-gamma geophysical logging may be necessary to estimate porosity. A logging operation with the capability of calculating porosity from logs taken in variable diameter boreholes should be used.

Vertical direction of ground-water flow may be estimated when water density is constant by placing packers at various depths in the borehole and measuring water levels. At this time, water samples could also be collected. However, for reliable and long-term measurements of vertical direction of flow, particularly when water density varies with depth, specially constructed wells open to different depths would be required. Also, the water-density profile, corrected for pressure and temperature, would have to be determined. 
To evaluate geophysically determined porosity and to estimate vertical hydraulic conductivity, laboratory analyses of cores are required. Intervals to be cored should be chosen only after a physically plausible hydrogeologic description of the site is available. Additional laboratory analyses that could be performed on cores from the unconsolidated section are discussed in a report prepared by the California Department of Water Resources (1971). Table 1 summarizes the borehole data-collection methods. 


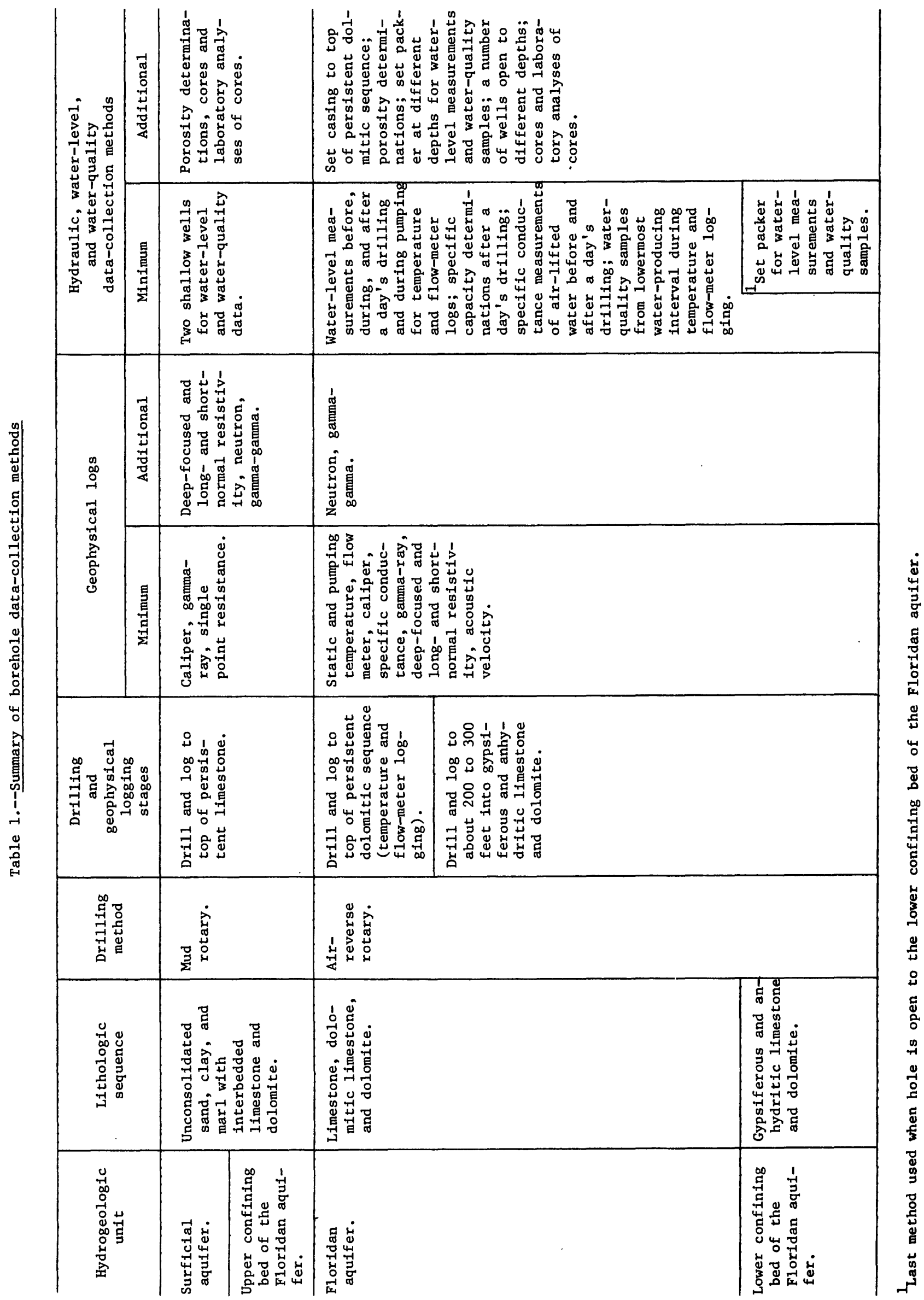


Applin, P. L., 1951, Preliminary report on buried pre-Mesozoic rocks of Florida and adjacent. states: U.S. Geological Survey Circular 91, 28 p.

California Department of Water Resources, 1971, Sea water intrusion: aquitards in the coastal ground water basin of Oxnard Plain, Ventura County: State of California Bulletin 63-4, $569 \mathrm{p}$.

Hickey, J. J., 1977, Hydrogeologic data for the McKay Creek subsurface-injection test site, Pinellas County, Florida: U.S. Geological Survey OpenFile Report 77-802, 62 p.

1979, Hydrogeologic data for the South Cross Bayou subsurface-infection test site, Pinellas County, Florida: U.S. Geological Survey Open-File Report 78-575, $87 \mathrm{p}$.

Hickey, J. J., and Barr, G. L., 1979, Hydrogeologic data for the Bear Creek subsurface-injection test site, St. Petersburg, Florida: U.S. Geological Survey Open-File Report 78-853, 57 p.

William F. Guyton and Associates, 1976a, Hydraulics and water quality: Consultants report prepared for Swift Agricultural Chemicals Corp., Manatee mine site, in files of Southwest Florida Water Management District.

1976b, Test hole geophysics and borehole flow: Consultants report prepared for Swift Agricultural Chemicals Corp., Manatee mine site, in files of the Southwest Florida Water Management District. 


1. (5)

18

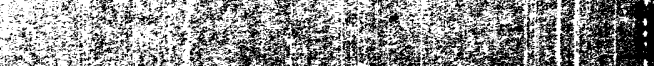

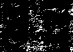

1.x.
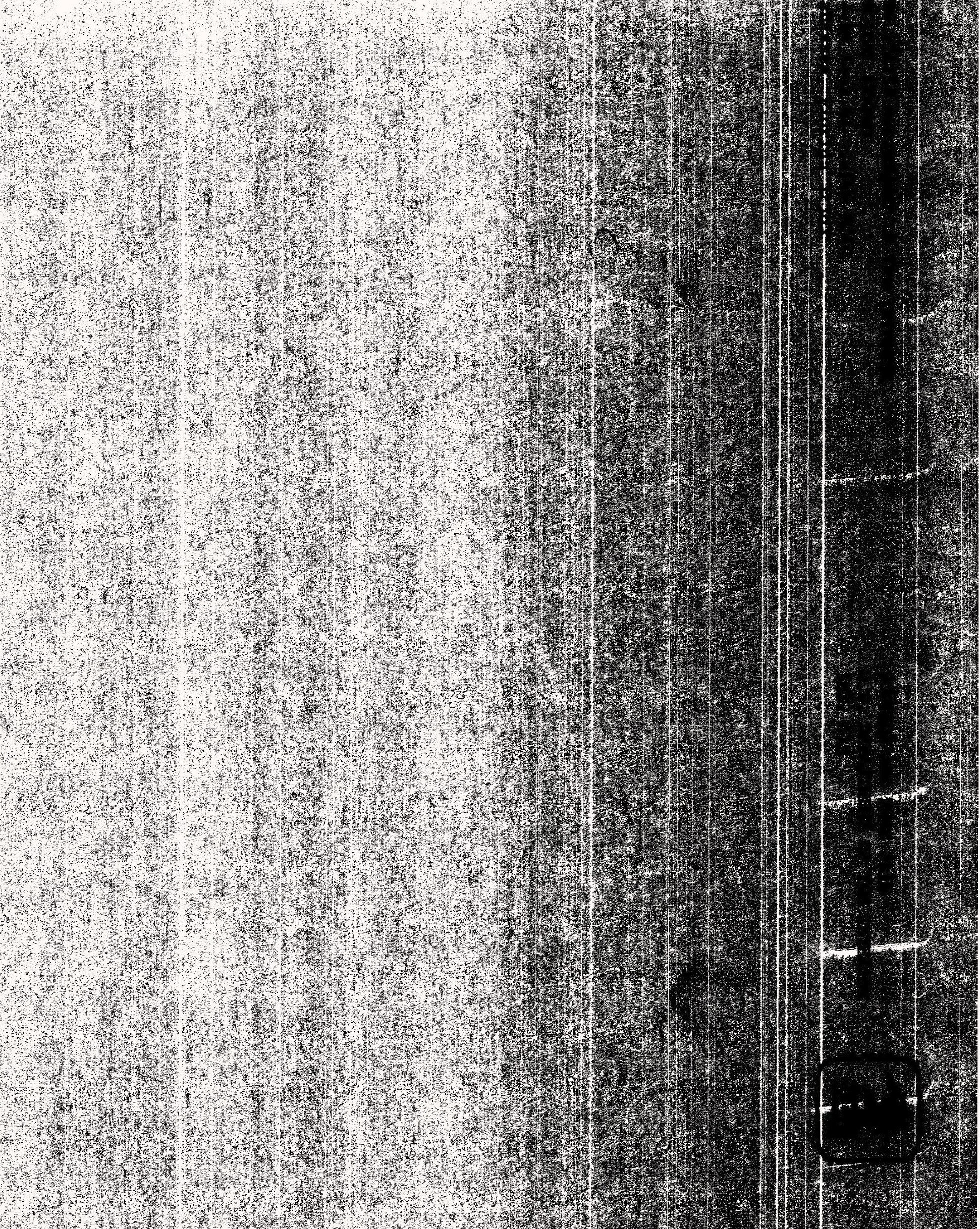